\title{
Az Európai Unió e-Inclusion programja és a magyarországi helyzet
}

A VII. Szociális Informatikai Műhelykonferencián 2007. májusában elhangzott előadás az Európai Unió szociális informatikai politikáját és annak 2007ig elért eredményeit értékeli. Az eInclusion politika ambiciózus céljait a 2006. évi rigai miniszteri csúcstalálkozó fogalmazta meg. E célok megvalósítása elsősorban az úgynevezett „nyílt koordinációs módszer” segítségével történik, a folyamat monitorozása azonban mind az EU szintjén, mind Magyarországon nehézségekbe ütközik. Hiányoznak az egységes indikátorok és összehasonlítható statisztikai adatok, melyek segítségével a döntéshozók és az érintett érdekcsoportok az Unió minden tagországa és valamennyi leszakadással fenyegetett társadalmi csoportja pontosabban fogalmazhatná meg céljait, és nyomon követhetné azok teljesülését. A tanulmány magyarországi adatokkal illusztrálja, hogy mely területeken ismert összehasonlítható módon az ország „eInclusion-érettsége”, továbbá rámutat azokra a területekre, ahol nem áll rendelkezésre ilyen információ.

Kulcsszavak: szociális informatika, társadalmi befogadás, indikátorok, társadalmi kirekesztés, informatikai akadálymentesítés, Európai Unió

\section{Szerzői információ:}

\section{Futó Péter}

Szociológus, a Budapesti Corvinus Egyetem Szociológia és Szociálpolitika Intézetének tudományos munkatársa, egyetemi oktató, valamint a Mixolid Tanácsadó Iroda szakértôje. Kutatási és oktatási területe: az infokommunikációs technikák elterjedésének társadalmi hatásai és az IKT hasznosítása a gazdaságban, valamint az államigazgatásban. Az utóbbi években az alábbi projektekben vett részt kutatóként, illetve tanácsadóként: „Az információs technikák elterjedésének hatása a Kaposvár környéki települések helyi társadalmának alakulására" (2004); Statistical Indicators for Benchmarking Information Society, SIBIS (2005); a Nemzeti Széles sávú Stratégia kidolgozása (2005); Az infokommunikációs technikák által lehetôvé tett outsourcing és offshoring tevékenységek Magyarországon (2005 és 2007); eInclusion@EU (2006); ICT for ALL (2007).

E-mail: peter.futo@uni-corvinus.hu

\section{Kollányi Bence}

Szociológus, médiaszociológia szakirányon végezte tanulmányait az Eötvös Loránd Tudományegyetem Társadalomtudományi Karán. Jelenleg a Corvinus Egyetem szociológiai doktori programjának hallgatója. 2004 óta vesz részt az ITTK munkájában, 2005-tól a központ munkatársaként. Fóbb kutatási területei: az információs társadalom fejlettségének mérése, a humán tốke és a nemzetközi versenyképesség összefüggései, valamint az információs társadalom építésének stratégiái. 
Így hivatkozzon erre a cikkre:

Futó Péter, Kollányi Bence. „Az Európai Unió e-Inclusion programja és a magyarországi helyzet”. Információs Társadalom VII, 3. szám (2007): 115-124. = https://dx.doi.org/10.22503/inftars.VII.2007.3.7 ए

A folyóiratban közölt müvek

a Creative Commons Nevezd meg! - Ne add el! - Így add tovább! 4.0

Nemzetközi Licenc feltételeinek megfelelően használhatók. 


\section{KUTATÁSI JELENTÉS}

Futó Péter - Kollányi Bence
Az Európai Unió $e$-Inclusion
programja és a magyarországi
helyzet

A VII. Szociális informatikai Múhelykonferencián elhangzott előadás.

Budapest, 2007. május 9.

\section{Az Európai Unió e-Inclusion programiának céljai}

Az Európai Unió szociális informatikai politikája most alakul ki, illeszkedve a "Társadalmi integráció” és az „Információs társadalom” már korábban intézményesített programjaihoz. Az e-Inclusion program kiemelt, 2010-ig megvalósítandó céljait az EU illetékes minisztereinek részvételével 2006-ban tartott rigai konferencia deklarációja a következókben foglalja össze:

- Felére kell csökkenteni a leszakadással fenyegetett csoportok és a többségi társadalom között tátongó szakadékot. (Megnevezett csoportok: idősek, fogyatékossággal élók, munkanélküliek.)

- 90\%-osra kell növelni a széles sávú „lefedettséget”.

- Minden nyilvános hálózati honlapot hozzáférhetővé kell tenni a leszakadással fenyegetett csoportok számára.

- Kötelezôvé kell tenni a hozzáférhetôségre vonatkozó szabványokat.

1. táblázat. A „rigai deklaráció” súlyponti terïletei

\begin{tabular}{|l|l||}
\hline \multicolumn{1}{|c|}{ Feladatok szerint } & \multicolumn{1}{|c|}{ Célcsoportok szerint } \\
\hline $\begin{array}{l}\text { Az IKT-eszközök hozzáférhetốvé tétele } \\
\text { (e-Accessibility) }\end{array}$ & $\begin{array}{l}\text { Idósek IKT-eszközökkel való támogatása } \\
\text { (e-Ageing) }\end{array}$ \\
\hline $\begin{array}{l}\text { Az IKT használatának képessége. Képzés, oktatás } \\
\text { (e-Competences) }\end{array}$ & $\begin{array}{l}\text { Kedvezốtlen adottságú térségek, települések (kis- } \\
\text { települések, kedvezốtlen helyzetú régiók) felzár- } \\
\text { kóztatása (Geographical e-Inclusion) }\end{array}$ \\
\hline $\begin{array}{l}\text { Elektronikus kormányzati szolgáltatások társadalmi } \\
\text { befogadást ösztönzố elemei (Inclusive } \\
\text { e-Government) }\end{array}$ & $\begin{array}{l}\text { Szociokulturális szempontok alapján történó felzár- } \\
\text { kóztatás (pl. marginalizált fiatalok, kisebbségek, } \\
\text { bevándorlók, munkanélküliek, fogyatékossággal } \\
\text { élók IKT-eszközökkel való integrálása a társada- } \\
\text { lomba (Socio-Cultural e-Inclusion) }\end{array}$ \\
\hline
\end{tabular}

A súlyponti területek kijelölésének nagy jelentôsége van, mert ezek alkotják az uniós e-Inclusion politika fogalmi kereteit. A deklarációban az EU - több előzetes, kísérleti fogalmi kerettel való kísérletezést követốen - „letette a garast” az e-Inclusion egyfaj- 
ta fogalmi tisztázása mellett. Az új politikaterületek esetében ez mérföldkố szokott lenni. Például e „rigai területek” szerint fogalmazták meg az egyes tagországoknak kiküldött „e-Inclusion érettség” kérdő́iveket (úgynevezett „State of play” kérdőívek). Várható, hogy a strukturális alapokból megítélt támogatásoknál is irányadó lesz, hogy a projekt illik-e a ,rigai” keretbe.

\section{A politika eszközrendszere}

A Rigában deklarált társadalmi befogadási célok igen ambiciózusak. Sem megvalósíthatóságuk, sem pedig teljesülésük ellenốrizhetôsége nem lesz automatikus.

A célokat csak akkor lehet megvalósítani, ha az Unió és annak tagállamai megalkotják és végigviszik a kapcsolódó koncepciókat, tisztázzák a hatásköri, illetékességi kérdéseket, megoldják a finanszírozással és a kapacitásokkal kapcsolatos problémákat. Még tisztázásra vár, hogy miként kívánják mindezt megvalósítani, milyen eszközök állnak rendelkezésükre?

Az EU eszközrendszere az alábbi módon csoportosítható:

1. Nyílt Koordinációs Módszer (erkölcsi jellegú, puha ösztönzókkel dolgozó, példamutatáson alapuló politikai instrumentum),

2. kötelezô erejú jogszabályok és direktívák, valamint ajánlott szabványok (jogszabály ezeket is kötelezóvé teheti),

3. támogatások a strukturális alapokból (anyagi ösztönzés).

A fenti séma minden uniós szabályozási területre vonatkozik. A nagyobb súlyú területeken nagy hatású jogszabályok vannak érvényben, és bőséges anyagi támogatás áll rendelkezésére (például a regionális fejlesztést nagy támogatási keret, a környezetvédelmet pedig számos direktíva segíti). A kisebb súlyú területek a nagyobbaknál lobbiznak célcsoportjaik anyagi és jogi támogatásáért.

Vizsgáljuk meg a fenti három eszközcsoport alkalmazásának helyzetét az $\ell$-Inclusion program esetében.

\section{Nyilt Koordinációs Módsæer (Open Method of Coordination, OMC)}

Ez a „módszer” valójában egy olyan politikai folyamat menedzselésére szolgál, melynek az alábbi összetevói, illetve mérföldkövei vannak:

2. táblázat. Nyílt Koordinációs Módszer

\begin{tabular}{|l|l|}
\hline \multicolumn{1}{|c|}{ Általában } & \multicolumn{1}{|c|}{ Az -Inclusion esetében } \\
\hline A tagállamok mẹgállapodnak a közös célokban. & $\begin{array}{l}\text { Az e-Inclusion politika jelenlegi céljait a rigai mi- } \\
\text { niszteri konferencia (34 ország) deklarációja hatá- } \\
\text { rozza meg. }\end{array}$ \\
\hline Konzultáció az érdekcsoportokkal, közzététel & $\begin{array}{l}\text { Érdekcsoportok: kirekesztéssel fenyegetettek ér- } \\
\text { dekképviseletei és az IKT-ipar szakmai szervezetei }\end{array}$ \\
\hline
\end{tabular}




\begin{tabular}{|c|c|}
\hline Általában & Az e-Inchusion esetében \\
\hline $\begin{array}{l}\text { A közös programot az ajánlások, a benchmarking és a } \\
\text { best practices alapján országszintû́ programokra bont- } \\
\text { ják le, és összehangolják a támogatásokkal és a jog- } \\
\text { szabályokkal. }\end{array}$ & $\begin{array}{l}\text { Magyarországon a módszer adaptációs tervének } \\
\text { elsố változata elkészült, de még nincs társadalmi vi- } \\
\text { tára bocsátva. }\end{array}$ \\
\hline $\begin{array}{l}\text { Indikátorokat jelölnek ki, intézményi-jogi és sta- } \\
\text { tisztikai adatokat gyújtenek. }\end{array}$ & $\begin{array}{l}\text { Példák: } \\
\text { • „e-Inchusion@EU” projekt 2005-2006: Tudásbázis } \\
\text { összeállítása. } \\
\text { • e-Inclusion országkérdőiv: puhatolózás az } \\
\text { e-Inchusion helyzetérốl az egyes tagállamokban. } \\
\bullet \text { „ICT for ALL” projekt 2006-2008: indikátorok ki- } \\
\text { dolgozása. }\end{array}$ \\
\hline $\begin{array}{l}\text { A folyamat mérföldkövei: konferenciák, magas } \\
\text { szintú deklarációk, kutatási és tanácsadási projek- } \\
\text { tek indítása és eredményeik közzététele. Kiemelt } \\
\text { eredménynek számít egy-egy országlista közzététe- } \\
\text { le. }\end{array}$ & $\begin{array}{l}\text { Workshop vagy konferencia szinte havonta van az } \\
\text { e-Inclusion témában. } \\
\text { Hiányok: nincs átfogó uniós kutatási eredmény, } \\
\text { nincs évkönyv, nincs összehasonlító statisztika. } \\
\text { Csak néhány releváns mutatóra lehet országlistát } \\
\text { összeállítani. }\end{array}$ \\
\hline
\end{tabular}

A folyamat menedzselését az Európai Bizottság Információs Társadalom és Média Fốigazgatóságán belül egy néhány fốs részleg, az „ICT for Inclusion Unit” végzi, amely a felmérések lebonyolítását és a témával foglalkozó tanulmányok kidolgozását, a releváns honlapok gondozását, valamint a workshopok és konferenciák megrendezését - közbeszerzési pályázatok útján - teljes mértékben kiszervezi különféle tanácsadó és kutató intézményeknek.

- Az „e-Inclusion@EU” projekt célja az volt, hogy tudásbázist állítson össze az e-Inclusion területéról a döntéshozók és a szélesebb szakmai közönség számára. A projekt keretében 2005 és 2006 folyamán az EU valamennyi tagországában és Svájcban feltárták és összegyưjtötték a társadalmi befogadás digitális eszközökkel történő elôsegítésének törvényi és intézményi körülményeit, az érdekcsoportokat, a tárgyra vonatkozó kutatásokat és statisztikákat, a „legjobb gyakorlatokat”, valamint a témával foglalkozó rendezvényeket és honlapokat. Továbbá a projekt során több workshopot is rendeztek, melyeken az érdekeltek (stakeholders) széles köre jelent meg. A projekt tehát nem kutatási program, hanem úgynevezett „Coordination Action” volt, a megvalósítására létrehozott nemzetközi konzorciumot az Empirica tanácsadó vállalkozás koordinálta. A Corvinus Egyetem Szociológiai és Szociálpolitikai Intézete összekötố szerepet töltött be a többi közép- és kelet-európai ország felé.

- Az „ICT for ALL" címú, szintén uniós finanszírozású projekt 2007-ben is folytatódik. Célja az e-Inclusion témájában hasznosítható statisztikai indikátorok összegyưjtése és továbbfejlesztése az alábbi célcsoportok esetéberì: idősek, fogyatékossággal élók, munkanélküliek és migránsok. A projekt részeként elkészül egy kérdőíves felmérés terve és megvalósul ennek kismintás próbakérdezése is. A nemzetközi konzorcium vezetője a lengyelországi székhelyű ASM piackutató és tanácsadó vállalat (ASM Market Research and Analysis Centre Ltd.). 


\section{Jogszabályok}

Az e-Inclusion politika legfontosabb uniós jogszabályai között központi jelentôségú az „Elektronikus hírközlő hálózatok és elektronikus hírközlési szolgáltatások keretirányelve” (Framework Directive, 2002/21/EK) és az „Egyetemes szolgáltatási irányelv az elektronikus hírközlő hálózatokhoz és elektronikus hírközlési szolgáltatásokhoz kapcsolódó felhasználói jogokról" (Universal Service Directive, 2002/22/EK). E jogszabályok többek között a következóket mondják ki: Az elektronikus hírközlési szolgáltatásokhoz való hozzáférés terén kötelező figyelembe venni a fogyatékossággal élő és a különleges szociális helyzetư felhasználók igényeit: a mozgássérültek számára megfizethető áron csatlakozást kell biztosítani a helyhez kötött (vezetékes) nyilvános telefonhálózathoz, a halláskárosultaknak nyilvánosan hozzáférhetố szövegmegjelenítố telefonokat, a látáskárosultaknak pedig általuk is olvasható részletes számlákat kell a rendelkezésére bocsátani.

A „Közbeszerzési irányelv” (2004/18/EC) a szociális szempontból kifogásolhatóan viselkedó vállalatokat kizárja a közbeszerzésból. A szerzói jogról szóló irányelv (2001/29/EK) kimondja, hogy a fogyatékossággal élók számára alternatív formákban történố másolás nem sérti a szerzói jogot. További fontos, idetartozó jogszabályok még a munkahelyi esélyegyenlőséget előíró irányelvek.

\section{Anyagi támogatás}

Az EU az elmúlt évtizedben a strukturális alapokból támogatott projektek keretéból számos olyan kezdeményezéshez, beruházáshoz, továbbá intézményfejlesztési, múszaki fejlesztési és társadalomkutatási programhoz nyújtott támogatást, amelyek a szociális informatika céljait valósították meg. Például a Phare programban számos magyar példa van etnikai, regionális, fogyatékossági vagy munkanélküliségi alapon megítélt IKT fejlesztési támogatásra.

\section{Az e-Inclusion szintjét tükrözó indikátorok fejlesztése}

Az e-Inclusion politika megvalósítási folyamatát és a célok eléréséhez vezetô út egyes fázisait csak annak tisztázása után lehet monitorozni, hogy mit jelent „a szakadék felére csökkentése”, és mit is jelent egy ország „érettsége” az e-Inclusion terén. Mindehhez indikátorokat kell kidolgozni, és méréseket kell végezni.

A stratégiai gondolkodás egyik alaptézise, hogy mérés és értékelés nélkül nem beszélhetünk változásról. Az e-Inclusion stratégia meghatároz ugyan kiemelt beavatkozási területeket (ilyenek például a széles sávú internettel lefedett területek vagy az akadálymentesen hozzáférhető kormányzati honlapok aránya), ugyanakkor jelenleg még ezeknek a mérési módszerei sem kellốen kidolgozottak.

Meg kell tervezni, hogy miként jellemezzük adatok segítségével az elektronikus eszközök használata területén megvalósuló társadalmi integrációt. Ezt az e-Inclusion politika által támogatott célcsoportokra való bontásban kell megvalósítani, hiszen másként kell jellemezni a fogyatékossággal élő személyek bevonásának szintjét, mint azt, hogy 
például az idősek vagy a munkanélküliek esetében milyen mértékben valósult meg az e-Inclusion. Az indikátoroknak részletes bontásban kell tükrözniük az e-Inclusion politika által támogatott és szabályozott technológiák (internet, mobiltelefon, digitális TV és az ún. „asszisztív technológiák”) tényleges felhasználását, ami önálló életvitelt tesz lehetốvé az idôs vagy fogyatékossággal élő személyek számára is.

Az e-Inclusion jellegzetes elemi indikátora egy hányados: a számlálóban valamilyen technikai eszköznek vagy valamilyen készségnek a leszakadással fenyegetett célcsoportban mért aránya, a nevezóben pedig ugyanannak az eszköznek vagy készségnek az ország teljes populációjában megállapított elterjedtsége áll. (Ilyen például a széles sávú internet elterjedtségi aránya a látáskárosultak körében, vagy az ECDL szintú informatikai tudással rendelkezók aránya a kisebb városokban és a falvakban, mindkét esetben a teljes lakosságra vetítve.)

A kompozit indikátor egyetlen országjellemzó, amely egy számos elemi indikátor alapján számított, tömörített adattal fejezi ki egy ország e-Inclusion érettségét. Ez általában a fentiekben definiált elemi indikátorok súlyozott összege.

Jelenleg célzottan az e-Inclusion szintjének indikátoraira vonatkozó ajánlások már születtek, de adatfelvétel még nem volt, fóként azért, mert ez drága, rétegezett mintavételt igényel.

\section{A SIBIS (Statistical Indicators Benchmarking the Information Society) projekt}

Az Európai Unió nem elóször találkozik azzal a problémával, hogy statisztikai rendszerének merevsége miatt az információs társadalom vonatkozásában nem képes valamennyi tagállamban kellóen mély adatokat elóállítani. Az Európai Statisztikai Hivatal, az Eurostat által az információs társadalom fejlettségére vonatkozóan elvégzett mérések megújítására tett átfogó kísérletet a 2001 januárjától 2003 szeptemberéig lezajlott SIBIS projekt, amelyhez akkor teljes indikátorrendszert dolgoztak ki. A SIBIS mutatók előállításához szükséges adatokat az EU akkori tagállamai mellett többek között a tíz csatlakozásra váró országban is rögzítették egy pilot felmérés keretében. A munka egyik legfontosabb eredménye a digitális megosztottságot egyetlen érték segítségével kifejezó komplex mutató kidolgozása volt. A ma már kezdetlegesnek tekintett Digital Divide Index (DIDIX) az internet és a személyi számítógépek használatának mértékét, valamint az otthoni hozzáférés arányát tükrözte. A SIBIS projekt végrehajtásával az Empirica nemzetközi kutató és tanácsadó vállalatot bízták meg, és abban a Budapesti Közgazdaságtudományi Egyetem Szociológia és Szociálpolitika Tanszéke is részt vett.

Az e-befogadás témaköre azonban a digitális megosztottság dichotómiájánál (a hozzáférés meglétének vagy hiányának kérdéseinél) lényegesen többet foglal magában. A rigai nyilatkozat értelmében növelni kell a széles sávú internettel lefedett földrajzi területeket, egyenlô esélyeket biztosítva a kisebb településeknek és az elmaradottabb régióknak, továbbá akadálymentes hozzáférést kell biztosítani a közcélú honlapokhoz minden internetfelhasználó számára. 
Javaslat az e-Inchusion országos szintjét tükrözó kompozit indikátor bevezetésére

Az Empirica vállalat a „rigai csúcshoz” kapcsolódva bemutatta elképzelését egy új, a korábbihoz hasonló, de egyszerúbben értelmezhetố, komplex e-Inclusion indikátor bevezetéséról. Ez az e-Inclusion Index ( $(I I x)$ elnevezésú mutató a szimpla hozzáférésen túllépve négy dimenziót vizsgál. Figyelembe veszi a tényleges használatot („internetalapú szolgáltatás igénybevétele legalább hetente egyszer"), a használathoz szükséges felkészültséget („e-készségek”), valamint két kiemelt, az esélyegyenlőséggel és az akadálymentesítéssel összefüggố változót, nevezetesen a széles sávú internetszolgáltatásokkal lefedett területek arányát és a teljes mértékben akadálymentesített kormányzati honlapok arányát.

\section{Jogi és intézményi indikátorok}

A statisztikai indikátorok mellett léteznek országok közötti összehasonlítást lehetôvé tevố jogi és intézményi indikátorok is. Ilyen mutató például az, hogy valamely országban bevezettek-e egy-egy kiemelten fontos jogszabályt és kialakult-e a jogszabály betartását figyelemmel kísérô, a jogkövetố magatartást kikényszerítő intézményrendszer, és ha igen, akkor milyen mélységben. Ilyen indikátorokhoz vezetnek továbbá az állami szereplók és a civil érdekcsoportok konzultációjának rendszerességére, tartalmára és eredményeire vonatkozó kérdések. E kvalitatív indikátorok forrásai általában szakértói interjúk vagy a kormányhivatalok által az országkérdőívekre adott válaszok. A jogi és intézményi indikátorok használatával kapcsolatosan is indult már precedensértékú uniós projekt: a bevándorlókra és a menekültekre vonatkozó jogszabályok harmonizációja. Az e-Inclusion „érettségének” mérése terén a jogi és intézményi indikátorok alkalmazása még csak terv.

\section{Digitális megosztottság Magyarországon a felmérések eredményeinek tükrében}

Bár az Európai Unió a rigai csúcstalálkozón ambiciózus célokat állított a tagállamok elé, adós maradt a változások mérésével. A célok kitûzésének idôpontjában nem történt meg a „mindenkit befogadó információs társadalom” aktuális állapotának, fejlettségi szintjének felmérése, így négy évvel késóbb nehéz lesz erôteljes érveket felhozni akár az uniós célok megvalósulása mellett, akár ennek a cáfolatára.

Jelenleg kevés adat áll rendelkezésre ahhoz, hogy megmondjuk, Magyarország önmagában véve - milyen ,érettségi” szinten áll az e-Inclusion terén. Azt pedig, hogy ez más EU-országokhoz képest mekkora lemaradást vagy éppen felzárkózást jelent, adatok híján nem tudja senki sem megállapítani, pedig enélkül nem múködhet az EU úgynevezett Nyílt Koordinációs Módszere.

Az információs társadalom szempontjából veszélyeztetett csoportok egy részére vonatkozóan a SIBIS projekt elindítása óta nem születtek európai szinten mért, megbízható adatok. A kisebbségek vagy a fogyatékossággal élók információs és kommunikációs szokásairól ma nagyon keveset tudunk: bizonyos mérések folytak, ám teljesen esetlegesen, s így az országok összehasonlíthatósága nem biztosított. 
Vizsgáljuk meg a rendelkezésre álló magyarországi adatgyújtésekre támaszkodva a hazai társadalmat az e-befogadás szempontjából! A hazai digitális megosztottsággal foglalkozó irodalom és a rendelkezésre álló statisztikai adatok alapján a legfontosabb törésvonalakat könnyen felismerhetjük. Ugyanakkor, ha a tágabb értelemben vett digitális esélyegyenlőséget és az úgynevezett „e-beágyazottságot” vizsgáljuk, több területen is adathiányba ütközünk. A közszféra akadálymentes honlapjainak elterjedtségére vonatkozóan például egyáltalán nincsenek adatok.

Az IKT használatával kapcsolatos felmérések között lehet találni rendszeresen mért, megbízható adatforrásokat. Könnyen találunk például a kistelepüléseken és a gazdaságilag elmaradott régiókban élő lakosság IK'T-használatára vonatkozó felméréseket. Az adatok szerint a közép-magyarországi régióban háromszor gyakoribb az otthoni internetkapcsolat megléte, mint az ország elmaradottabb térségeiben, míg a kistelepülésen élók 30\%-kal alacsonyabb arányban férnek hozzá a világhálóhoz (forrás: WIP, 2006). Ugyanígy megismerhetjük az IKT használatában megmutatkozó különbségeket az életkorral vagy az iskolai végzettséggel összefüggésben is.

Léteznek azonban olyan társadalmi csoportok, amelyekról nem állnak rendelkezésre pontos statisztikák: ez a bizonytalanság adódhat a csoport határainak elmosódottságából, illetve a kérdőíves módszerek korlátaiból. Az utóbbira jó példa a munkanélküliekre vonatkozó adatok körüli bizonytalanság, míg az elóbbire az olyan, az etnikai hovatartozással kapcsolatos (és a szociológusok körében is rendszeresen vitákat kiváltó) adatok utalnak, mint amilyenek például a romákra vonatkozó statisztikákban lelhetók fel. Végül léteznek olyan csoportok, amelyekról szinte egyáltalában nem rendelkezünk reprezentatív adatokkal. Ezek közül az e-befogadással kapcsolatban a fogyatékossággal élóket emelhetjük ki.

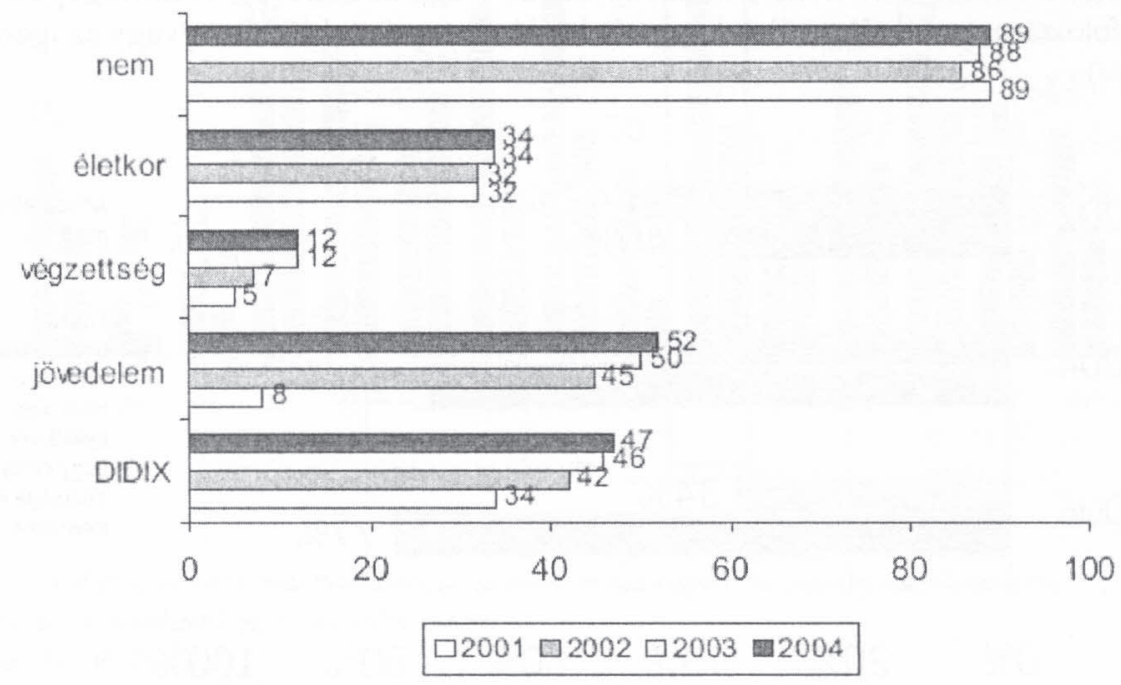

1. ábra. A digitális szakadék indexei Magyarországon, 2001-2004*

* A leszakadással fenyegetett csoport infokommunikációs helyzete nulla közeli értékek esetén nagyon hátrányos. 100 közeli értékek esetén viszont nincs sem digitális kirekesztés, sem hátrányos helyzet. Forrás: WIP 
A számítógép- és internethasználatot több hazai kutatóintézet is vizsgálja. A lakosság releváns adatait és az internet társadalmi hatásait 2001 óta Magyarországon kérdőíves felmérések segítségével rendszeresen méri a World Internet Project (WIP), valamint más, eseti jellegú adatgyújtések is folynak. A Tárki-Ithaka-ITTK-kutatócsoport gondozta WIP alapadatai alapján a SIBIS projekt keretében definiált DIDIX mutatót is több alkalommal meghatározták.

Az elóbbi, 1. ábrán a digitális törésvonalak jellemző dimenzióit láthatjuk. Amikor a grafikon értékei elérik a 100\%-ot, az adott dimenzióban nem mérhetố többé különbség a vizsgált csoportok között.

Magyarországon 2000 után a számítógép- és internethasználat terén viszonylag csekély különbség mutatkozott a férfiak és a nók között. Az életkori különbségek már lényegesen nagyobb mértékben jelentkeztek: az adatok azt mutatják, hogy a kor előrehaladtával egyre alacsonyabb szintû́ az információs és kommunikációs technológiák használata. Ez a különbség a legfrissebb 2006-os felmérés szerint is csak kismértékben csökkent. A DIDIX mutató elemzésének az a tanulsága, hogy ma Magyarországon az egyes társadalmi csoportok alacsony vagy magas internetezési és számítógép-használati aránya az iskolai végzettséggel mint magyarázó változóval áll a legszorosabb összefüggésben.

A hátrányos gazdasági helyzet elsốsorban az „internetkorszak” kezdeti éveiben jelentett nehezen leküzdhetố akadályt. Megfigyelhetó, hogy a jövedelemból adódó megosztottság évról évre kisebb mértékben jelentkezik a hazai társadalom IKT-használati mutatóiban. Ezek az eredmények lényegében egybevágnak a WIP hazai kutatásának legfontosabb tanulságával, miszerint az internethasználat elótt álló, úgynevezett materiális gátakat (például drága hozzáférés, számítógépek hiánya) fokozatosan felváltották a kognitív korlátok (az érdeklôdés és/vagy az igények hiánya).

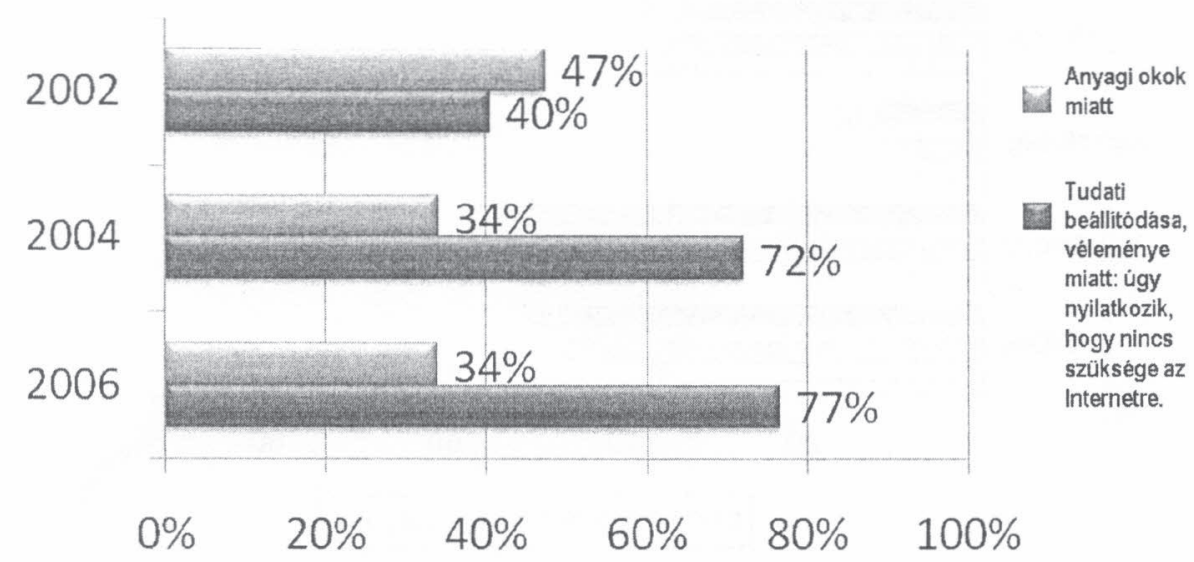

2. ábra. Miért nem hasønálja az internetet?

(A válaszok aránya az internet nem használatát indokoló összes válasz százalékában)

Forrás: WIP 2006. évi gyorsjelentés 
Az internetezés költségének fokozatos csökkenésével párhuzamosan tehát az anyagi korlátok említése néhány év alatt közel harmadával csökkent. A fenti ábrán jól látható, hogy ugyanezen idô alatt jelentôsen megnótt a kognitív szempontok szerepe az internettól való távolmaradás indoklásában. 2006-ban a nem internetező válaszadók 77\%-a említette az érdeklődés vagy a hozzáértés hiányát, amikor a WIP felmérés keretében arra kellett válaszolniuk, hogy miért nem használják az internetet. Ma Magyarországon a nem-internetezók körében még mindig 42,5 \%-os azon válaszolók aránya, akik szerint nem kerül hátrányba az, akinek nincs internet-hozzáférése.

A World Internet Project az elmúlt években több mint egy tucatnyi újabb országra is kiterjedt, ám a vizsgálatok eredményei ennek ellenére - az eltérô adatfelvételi módszerekból és az adatbázisok megosztásának hiányából következôen - ma még kevéssé használhatók fel az e-befogadás szintjeinek összehasonlító elemzésére. Az Európai Unió statisztikai hivatala által koordinált IKT-fókuszú vizsgálatoknak köszönhetôen ugyanakkor több fontos mutató már a rendelkezésünkre áll. Így megismerhetjük például a hazánkban alacsony idốskori internetezési mutatók alakulását más tagállamokban. A World Economic Forum nemzetközi e-felkészültségi vizsgálatát vezetô (jelenleg az egyik legfejlettebb információs társadalomként nyilvántartott) Dániában az 55 és 74 év közötti korcsoport tagjainak mindössze $27 \%$-a tekinthetô „digitálisan írástudatlannak”, míg ugyanez az érték Magyarországon jóval meghaladja a 80 \%-ot - az Unió átlaga ezen a téren $60 \%$ felett van.

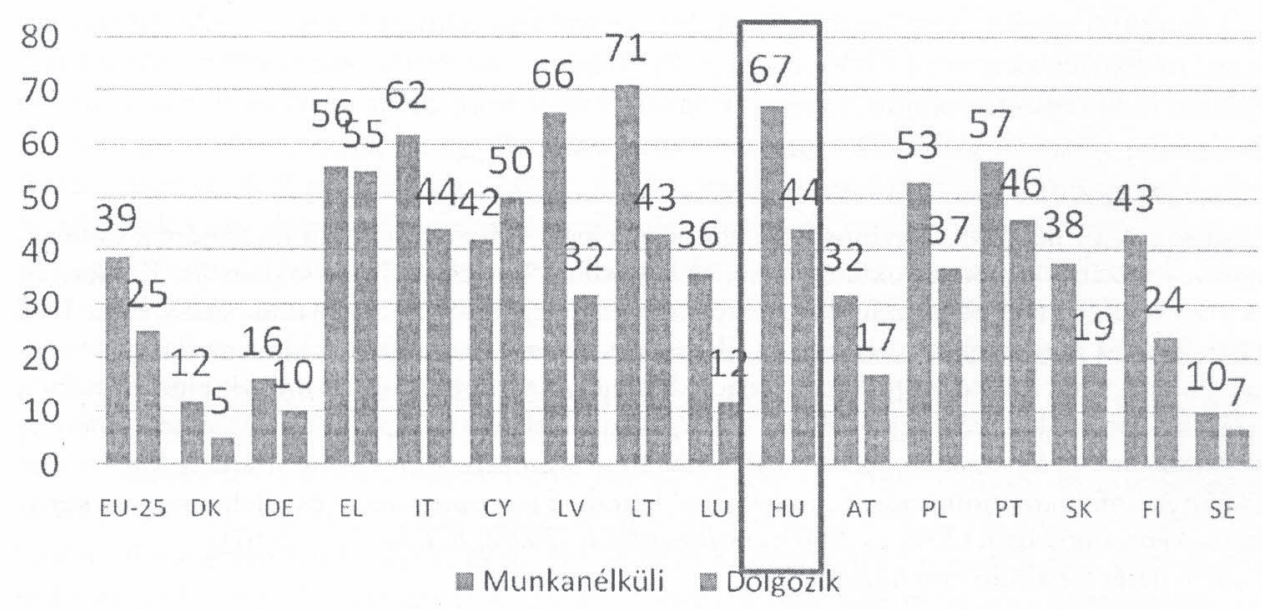

3. ábra. A digitálisan írástudatlan lakosság aránya aะ Európai Unió nélhány tagállamában, a válaszolók munkaeró-piaci pozíciója szerint

Forrás: EUROSTAT

A munkanélküliek Európa valamennyi országában jelentôsen elmaradnak munkahellyel rendelkezố társaiktól a digitális eszközök használatához szükséges készségek elsajátításában. Az Uniónak a közelmúltban kiadott gyorsjelentése szerint Magyarországon a jelenleg dolgozó válaszadók 44\%-a számolt be arról, hogy egyáltalában nem ért 
az IK'T-eszközök használatához. A munkanélküliek körében ez az arány eléri a 67\%-ot. Ez utóbbi nemcsak a tagállamok egyik legrosszabb értékét jelenti, hanem - figyelembe véve a dolgozók és a munkanélküliek helyzete közötti jelentốs különbséget - azt is kifejezi, hogy a társadalmi megosztottság a digitális technológiák használatára is kiterjed. 